Article

\title{
Foreign Ownership, Agency Costs, and Long-Term Firm Growth: Evidence from Korea
}

\author{
Young Mok Choi ${ }^{1}$ and Kunsu Park ${ }^{2, *(1)}$ \\ 1 College of Business Administration, Cheongju University, 298, Daeseong-ro, Cheongwon-gu, Cheongju-si, \\ Chungcheongbuk-do 28497, Korea; ymchoi@cju.ac.kr \\ 2 Bang College of Business, KIMEP University, Abay Ave 2, Almaty 050010, Kazakhstan \\ * Correspondence: kunsu.park@kimep.kz; Tel.: +7-702-172-4096
}

Received: 1 January 2019; Accepted: 11 March 2019; Published: 15 March 2019

check for updates

\begin{abstract}
This study examines the link between foreign ownership and firm value in the context of dividend payouts and long-term firm growth. Consistent with prior studies, we find that foreign ownership is positively related to firm value. Next, we find that changes in foreign ownership are negatively related to changes in agency costs, which is linked to the improvement of future firm profitability. We also find a positive relationship between foreign ownership and dividend payouts. We further find that dividend payouts are negatively related to 3-year-ahead and 5-year-ahead sales (or earnings) growth as a proxy for long-term firm growth. However, for firms with high foreign ownership, we find a positive relationship between dividend payouts and long-term firm growth. These findings indicate that foreign ownership has a moderating effect on dividend payouts and long-term firm growth. Overall, our results suggest that foreign investors are expected to provide managers with an incentive to pursue long-term value for the sake of shareholders by monitoring and disciplining managers. Our study contributes to a better understanding of the value-increasing effects of foreign ownership on firm value by demonstrating that the reduction in agency costs due to the foreign ownership effect is associated with higher growth rates and thus higher firm value. Our study also contributes to the literature on the foreign ownership-firm value nexus by showing that foreign investors play a crucial role in ensuring sustainable firm growth.
\end{abstract}

Keywords: foreign ownership; firm value; agency costs; dividend payout; long-term firm growth

\section{Introduction}

The issue of whether foreign ownership affects firm value has attracted significant research interest from both academics and practitioners over the past few decades [1-4]. Although previous studies focus on examining the relationship between foreign ownership and firm value, they lack specific evidence concerning how foreign ownership affects firm value. In contrast to prior studies, we identify the channels through which foreign ownership increases firm value-agency costs and long-term firm growth. Specifically, we investigate the value effect of foreign ownership in the following three ways: (1) the relationship between changes in foreign ownership and changes in agency costs; (2) the relationship between foreign ownership and dividend payouts; and (3) the moderating effect of foreign ownership on the relationship between dividend payouts and long-term firm growth.

Large outside shareholders and directors have been recognized as subjects that monitor managers and execute oversight [5-8]. However, domestic institutional investors and outside directors in most Korean public firms do not effectively monitor their managers. This ineffective monitoring occurs because domestic institutional investors are mainly the affiliates of chaebol or business-related firms and also because outside directors are usually chosen on the basis of personal networking or social ties with either CEOs or controlling shareholders. Many Korean firms belong to 
family-owned conglomerates, which are referred to as chaebol. The chaebol groups are dominant in the Korean economy [9]. Chaebols also have a significant influence on their affiliates' performance or profitability [10]. This indicates that domestic institutional investors and outside directors are not independent of CEOs or controlling shareholders.

On the other hand, foreign investors specialize in managerial monitoring and are recognized as ownership entities who are independent of managers and controlling shareholders $[1,2,11]$. Foreign investors protect minority shareholders against controlling shareholders by employing arm's-length monitoring [12]. Foreign investors also contribute to improving corporate governance by participating in firms' board of directors [13-15]. According to the Korea Supervisory Service (FSS), as of the end of 2016, foreign investors held approximately $35.1 \%$ of the total market capitalization of the Korean stock market. Foreign investors are classified into two types: individual and institutional investors. Most foreign investors are usually institutional investors. Specifically, foreign individual investors owned $3.6 \%$ of the total market capitalization of the Korean stock market. In the Korean stock market, foreign investors not only play a crucial role in corporate governance structure, but also serve as effective monitors of managerial actions [16].

Foreign institutional investors play a major role in monitoring and disciplining managerial actions, possibly leading to an improvement in corporate governance. Therefore, we predict that as foreign ownership increases, the monitoring of managers and controlling shareholders increases, resulting in a decrease in agency costs. The reduction in agency costs is associated with the improvement of a firm's profitability [17], implying its ability to increase dividend payouts. There may be a negative association between dividend payouts and earnings (or sales) growth because the equity needed to future investments decreases as dividend payout becomes high $[18,19]$. However, the increased profitability due to the decrease in agency costs can be linked to an increase in investment expenditures even though dividend payouts are high. Thus, the relationship between dividend payouts and future firm growth in the firms with high foreign ownership is expected to be positive. Based on this logic, we predict that, if investors (or markets) reasonably anticipate that firms with higher foreign ownership exhibit higher long-term firm growth, the effects of increased long-term firm growth may be incorporated into current firm valuation.

Using a sample of 8348 firm-year observations between 2001 and 2017, we first investigate the link between foreign ownership and firm value after controlling for previously identified determinants that affect firm value. Consistent with prior studies, we find that foreign ownership is positively and significantly related to firm value. Furthermore, we estimate change regressions to investigate the impact of changes in foreign ownership on changes in firm value. We find a positive relationship between changes in foreign ownership and changes in firm value, confirming our previous results using variable levels. Second, we examine the effect of changes in foreign ownership on changes in agency costs. We find that changes in foreign ownership are negatively and significantly related to changes in the expense ratio. We also find that changes in foreign ownership are positively and significantly associated with changes in asset utilization ratio. These findings suggest that foreign ownership is effective in reducing agency costs. Third, we explore whether foreign ownership is associated with dividend payouts. As expected, we find that foreign ownership is positively and significantly related to the level of dividends, indicating that firms with high foreign ownership pay more dividends. Our results suggest that the improved profitability due to the decrease in agency costs resulting from the monitoring effect of foreign investors is associated with higher dividend payouts. Finally, we investigate whether foreign investors affect a firm's long-term firm growth. Consistent with prior studies [19], we find that dividend payouts are negatively associated with long-term firm growth. Interestingly, however, for firms with high foreign ownership, we find a positive relationship between dividend payouts and long-term firm growth. This finding indicates that firms with higher foreign ownership have higher long-term firm growth even though they maintain a higher level of dividends.

Our study contributes to the literature by providing a better understanding of the value-increasing effect of foreign ownership on firm value. Prior studies document a direct and positive association 
between foreign ownership and firm value [1,3,4]. To our knowledge, despite the significant importance of agency costs in foreign ownership-firm value nexus, prior studies have not attempted to provide empirical evidence that foreign ownership can be effective in mitigating agency costs. In contrast, using the actual measurement of agency costs, we provide evidence concerning a specific mechanism through which foreign ownership increases firm value.

Our study also contributes to the literature on the foreign ownership-firm value nexus by showing that foreign investors play a crucial role in ensuring sustainable firm growth. Our empirical results confirm that foreign investors are expected to facilitate a firm's sustainable growth by reducing agency costs. Specifically, we find that changes in foreign ownership are negatively linked to changes in agency costs. We also show that the reduction in agency costs due to the foreign ownership effect is associated with higher growth rates and thus higher firm value.

Our study sheds light on the important role of foreign investors in the relationship between dividend payouts and long-term firm growth. Theoretically, it is recognized that there is a negative relationship between dividend payouts and long-term growth rates [20]. Our study extends the existing literature by providing new evidence that the negative relationship between dividend payouts and long-term growth rates is weaker for firms with high foreign ownership. Our evidence suggests that foreign ownership has a moderating effect on the relationship.

The remainder of this paper is organized as follows: Section 2 reviews prior literature and develops our hypotheses; Section 3 describes the sample selection and variable definitions; Section 4 presents the results; and Section 5 concludes the paper.

\section{Prior Literature and Hypothesis Development}

\subsection{Foreign Investors and Agency Costs}

Under the separation of ownership and control in firms, managers may pursue self-interest and private rent-seeking behavior, thus causing agency problems with shareholders [5,21,22]. As a result, shareholders will bear costs associated with the monitoring of managers' actions. Large outside shareholders, as well as outside directors, have been recognized as subjects that monitor managers and execute oversight. Grossman and Hart [5] and Shleifer and Vishny [6] argue that large outside shareholders actively monitor managers and possibly alleviate a free-ride problem, thus reducing agency costs. Likewise, prior studies claim that outside directors properly and effectively monitor managerial actions due to their reputational capital and their fear of shareholders' litigation [23-25].

However, in the Korean governance system, the monitoring role of large outside shareholders (especially domestic institutional investors) and outside directors has been a controversial issue. Academics and practitioners are concerned about the efficacy of the monitoring of domestic institutional investors and outside directors and have further questioned their independence from managers and controlling shareholders (or founding families).

Foreign investors are generally recognized as important entities that have the source and ability to effectively monitor managerial decisions in emerging markets. Khanna and Palepu [1] and Douma et al. [2] point out that the reason that domestic institutional investors in emerging markets cannot effectively monitor managers is the lack of investors' specializations and incentives. In a similar vein, Jeon et al. [16] emphasize the role of foreign investors as effective monitors in Korean stock markets. Mishra and Ratti [11] suggest that, unlike domestic institutional investors, foreign investors have the ability to influence a firm's decision-making due to the lack of business affiliations with the firm. Unlike domestic institutional investors and outside directors, foreign investors can be effective monitors of managers on behalf of shareholders' interests because they are more likely to demand higher corporate governance standards [26]. Accordingly, foreign investors are expected to play an important role in monitoring managers and controlling shareholders, thus mitigating agency problems. Therefore, we expect that higher foreign ownership will be associated with lower agency costs. 
Based on the above discussion, we propose the first hypothesis as follows (stated in alternative form):

Hypothesis 1 (H1). Ceteris paribus, changes in foreign ownership is negatively related to changes in agency costs.

\subsection{Foreign Investors and Dividend Payouts}

Prior studies document mixed evidence on the relationship between institutional ownership and dividend payouts [8,15,16,27-30]. Specifically, Zeckhauser and Pound [27] find no significant differences in dividend payouts between firms with and without large shareholders. In a subsequent study, Eckbo and Verma [28] document a positive and significant relationship between institutional shareholdings and dividends, consistent with the agency view that institutional investors pressure firms to pay dividends to mitigate agency costs associated with free cash flows. Short et al. [29] find that institutional ownership has a significantly positive impact on dividend payouts. In another study, Grinstein and Michaely [8] find no evidence that firms with higher institutional stock holdings pay more dividends. However, these studies have focused on institutional investors, not foreign institutional investors, in relation to dividend payouts. Turning to the role of foreign investors in corporate dividend decisions, Baba [30] finds that firms with higher foreign ownership have a higher likelihood of paying dividends. Similarly, Jeon et al. [16] show that foreign investors with a higher proportion of shareholdings (more than $5 \%$ ) are likely to exert significant influence over firms' payout decisions.

In the Korean stock market, foreign investors are expected to influence dividend decisions. Korea has a unique form of business conglomerates, known as chaebols. The family-run chaebols have dominated the Korean economy for several decades. The Economist describes the negative impact of chaebols on the Korean economy as "Nefarious schemes to pass on control to sons, avoid taxes and exploit company assets for the benefit of family members are widely discussed in private" [31]. Unlike developed countries such as the US and UK, Korea is characterized by relatively poor corporate governance, especially weak protection for minority shareholders. Controlling shareholders have a close relationship or social ties with managers and thus possibly have the power to expropriate minority shareholders by pursuing their private interests [32]. Moreover, domestic institutional investors play a limited role in monitoring managers and controlling shareholders. Given that the corporate governance system is weak in Korea, foreign investors are expected to pressure firms to improve corporate governance, especially the improvement of legal protection for minority shareholders; thus, foreign investors will create potential benefits for minority shareholders. Accordingly, better corporate governance due to the monitoring effect of foreign ownership will be more likely to be associated with a higher level of dividends in an effort to reduce expropriation by managers and controlling shareholders, consistent with the prediction of the La Porta et al.'s [33] outcome hypothesis. La Porta et al. [33] propose two competing hypotheses to explain the link between shareholder rights and corporate dividend policy, the outcome hypothesis and the substitute hypothesis. The outcome hypothesis proposes that the effectiveness of legal shareholders' protection enables minority shareholders to pressure firms to pay dividends. The substitute hypothesis predicts that firms will pay dividends to shareholders for the purpose of using their dividend policy as "a substitute for effective legal protection" (p. 27).

Based on the above reasoning, we expect that firms with higher foreign ownership will pay more dividends. We, therefore, formulate the second hypothesis as follows (stated in alternative form):

Hypothesis 2 (H2). Ceteris paribus, there is a positive relationship between foreign ownership and dividend payouts. 


\subsection{Foreign Investors and Long-Term Firm Growth}

Higgins [34] defines sustainable growth rates as the maximum ones that can be accomplished with only reserve capital within a firm while maintaining its target capital structure without any additional stock issuance. He shows that sustainable growth rates are equal to the growth rate of stockholders' equity. Sustainable growth rates can be represented as retention ratios multiplied by return on equity (ROE). Thus, if dividend payouts are high, the equity required for future investments decreases, which consequently has a negative relationship between dividend payouts and growth rates. However, this theoretical relationship holds only if firms raise additional capital from outside sources while maintaining their current target capital structure. In other words, such a relationship can be changed according to different target capital structure. This is because as firms grow, their debt capacity can be improved.

Several studies, including Myers [20], Fama and French [35], and Ibbotson and Chen [18], find a negative relationship between dividend payouts and earnings growth rates. Farsio et al. [36] show that firms have lower earnings in the long-run when they pay a higher level of dividends without any consideration of their investment expenditures. Similarly, Gill et al. [37] show that firms experiencing high growth rates or those anticipating high future growth rates tend to pay low dividends to avoid external financing, indicating a negative relationship between dividend payouts and sale growth. In a more recent study, using a sample of Australian firms, Dempsey et al. [19] also find a negative association between dividend payouts and sales growth.

Foreign investors can affect the association between dividend payouts and sales (or earnings) growth as a proxy for long-term firm growth. Regarding firms with high foreign ownership, foreign investors are expected to provide managers with an incentive to pursue a long-term value for the sake of shareholders by monitoring and disciplining managers. Consequently, it can lead to a decrease in agency costs, which indicates an improvement in profitability $[17,38]$. The increased profitability can result in an increase in investment expenditures even though dividend payouts are high. Thus, the relationship between dividend payouts and long-term firm growth in the firms with high foreign ownership is expected to be positive.

Based on the above logic, we propose the following third hypothesis (stated in alternative form):

Hypothesis 3 (H3). Ceteris paribus, there is a positive relationship between dividend payouts and long-term firm growth in firms with high foreign ownership.

\section{Data and Descriptive Statistics}

\subsection{Sample Selection}

We obtain ownership and financial data from the Korea Investors Service-Value (KIS-Value) database between 2001 and 2017. The KIS-Value database is provided by the National Information and Credit Evaluation (NICE), which is a leading provider of credit ratings in Korea. The reason why we use Korean data for the period is as follows. As an independent authority, the Korean Accounting Standards Board (KASB) was founded in September 1999 to develop and issue accounting standards. Since July 2000, the KASB has amended corporate accounting standards for consecutive years, which has affected firms' financial statements more than ever before. Thus, to minimize the effect of modifying corporate accounting standards, we use the sample period between 2001 and 2017 (See http:/ / www.aossg.org/docs/Meetings/Meeting_Nov_2013/Agenda_paper_3.3_2013_ Annual_AOSSG_Meeting.pdf). Our sample covers non-financial companies that are listed on the Korea Exchange (KRX) and whose fiscal year ends in December. Sample selection bias is, however, not a serious concern since a majority of Korean firms have their fiscal year ending in December. We also delete firm-year observations with missing values. Finally, we winsorize all continuous variables 
at the $1 \%$ and $99 \%$ levels to reduce the effects of outliers. Our final sample contains 8348 firm-year observations for 663 firms between 2001 and 2017.

\subsection{Variable Descriptions}

Following prior studies $[3,4,39]$, we use Tobin's Q (Tobin_Q) as a proxy for firm value. We use foreign ownership (Foreign_Own) as a main explanatory variable. As predicted by Ferreira and Matos [3], we expect a positive relationship between foreign ownership and firm value.

We control for controlling shareholders' ownership (Control_Own). The relationship between controlling shareholders' ownership and firm value is unclear. We control for firm size (Firm_Size). The relationship between firm size and firm value is mixed. Berger and Ofek [40] and Ferreira and Matos [3] find that firm size is positively related to firm value, while Lang and Stulz [41] find that firm size is negatively related to firm value. We control for leverage (Leverage); its relationship with firm value is mixed. While Ferreira and Matos [3] find a positive relationship between leverage and firm value, Benson and Davidson [39] find a negative relationship. We use capital expenditures (Capital_Expen) as a proxy for firms' growth opportunities. As predicted by Aggarwal et al. [4], we expect a positive relationship between capital expenditures and firm value. We control for the level of cash dividends (Dividend) and expect a positive relationship between dividends and firm value. We use return on assets (ROA) as proxy for firms' profitability. Based on Aggarwal et al. [4], we expect a positive relationship between profitability and firm value. We provide more detailed definitions for all variables in Appendix A.

\subsection{Descriptive Statistics}

Table 1 presents the descriptive statistics of our sample firms. The mean (median) Tobin_Q is 1.1083 (0.9318). The distribution of Tobin_Q is right-skewed. The mean (median) Foreign_Own is $0.1110(0.0471)$, indicating that foreign investors account for about $11.10 \%$ of total shares outstanding in our sample. Foreign_Own has a right-skewed distribution. The mean (median) Control_Own is 43.14\% $(42.93 \%)$, indicating that controlling shareholders constitute a large proportion of a firm's outstanding shares. The large proportion of controlling shareholders' ownership suggests that the shareholders can greatly influence corporate decision making in the Korean stock market. The mean (median) value of Firm_Size is 26.7135 (26.4550). The mean (median) values of Leverage, Capital_Expen, and Dividend are $42.18 \%(42.43 \%), 1.55 \%(0.07 \%)$ and $0.88 \%(0.59 \%)$, respectively. The mean (median) value of ROA is $0.0452(0.0410)$. Turning to three proxies for agency costs, the mean (median) values of SGA_Sales, Net_SGA_Sales, and Sales_Asset are $0.1782(0.1099), 0.1695$ (0.1022), and $0.9220(0.8488)$, respectively.

Table 1. Descriptive statistics.

\begin{tabular}{lcccccc}
\hline Variables & $\mathbf{N}$ & Mean & Std. Dev. & 25th & Median & 75th \\
\hline Tobin_Q & 8348 & 1.1083 & 0.6452 & 0.7458 & 0.9318 & 1.2122 \\
Foreign_Own & 8348 & 0.1110 & 0.1428 & 0.0097 & 0.0471 & 0.1624 \\
Control_Own & 8348 & 0.4314 & 0.1686 & 0.3121 & 0.4293 & 0.5412 \\
Firm_Size & 8348 & 26.7135 & 1.4834 & 25.6731 & 26.4550 & 27.5130 \\
Leverage & 8348 & 0.4218 & 0.1982 & 0.2651 & 0.4243 & 0.5663 \\
Capital_Expen & 8348 & 0.0155 & 0.0802 & -0.0100 & 0.0007 & 0.0254 \\
Dividend & 8348 & 0.0088 & 0.0107 & 0.0000 & 0.0059 & 0.0125 \\
ROA & 8348 & 0.0452 & 0.0616 & 0.0156 & 0.0410 & 0.0751 \\
SGA_Sales & 8348 & 0.1782 & 0.1764 & 0.0628 & 0.1099 & 0.2167 \\
Net_SGA_Sales & 8348 & 0.1695 & 0.1719 & 0.0599 & 0.1022 & 0.2041 \\
Sales_Asset & 8348 & 0.9220 & 0.5314 & 0.5891 & 0.8488 & 1.1606 \\
Short_Debt & 8348 & 0.7156 & 0.1950 & 0.5963 & 0.7539 & 0.8679 \\
Firm_Age & 8348 & 3.4646 & 0.6757 & 3.3322 & 3.6636 & 3.8918 \\
Sales_Growth & 8348 & 0.0840 & 0.3147 & -0.0398 & 0.0493 & 0.1488 \\
Stock_Volatility & 8348 & 46.8924 & 19.2482 & 33.4774 & 43.2176 & 56.5658 \\
R\&D_Intensity & 8348 & 0.0099 & 0.0208 & 0.0000 & 0.0012 & 0.0097 \\
Retained_Asset & 8348 & 0.2807 & 0.2840 & 0.1223 & 0.2847 & 0.4681 \\
Asset_Growth & 8348 & 0.0763 & 0.1928 & -0.0155 & 0.0445 & 0.1291 \\
Foreign_Dummy & 8348 & 0.4994 & 0.5000 & 0.0000 & 0.0000 & 1.0000 \\
\hline
\end{tabular}


Table 2 shows the Pearson correlations among main variables. As expected, we find a positive and significant correlation between Tobin_Q and Foreign_Own and. Tobin_Q exhibits a significantly positive correlation with Firm_Size, Capital_Expen, Dividend, and ROA. We further find that Tobin_Q is negatively and significantly correlated with Control_Own.

Table 2. Pearson correlations among main variables.

\begin{tabular}{|c|c|c|c|c|c|c|c|c|}
\hline & (1) & (2) & (3) & (4) & (5) & (6) & (7) & (8) \\
\hline (1) Tobin_Q & 1.0000 & & & & & & & \\
\hline (2) Foreign_Own & $0.2279 * * *$ & 1.0000 & & & & & & \\
\hline (3) Control_Own & $-0.1146^{* * *}$ & $-0.1475^{* * *}$ & 1.0000 & & & & & \\
\hline (4) Firm_Size & $0.0571^{* * *}$ & $0.4503^{* * *}$ & $-0.0450 * * *$ & 1.0000 & & & & \\
\hline (5) Leverage & -0.0003 & $-0.1184^{* * *}$ & $-0.1166^{* * *}$ & $0.1852 * * *$ & 1.0000 & & & \\
\hline (6) Capital_Expen & $0.0607 * * *$ & 0.0188 & 0.0265 & $0.0425^{* * *}$ & $0.0526^{* * *}$ & 1.0000 & & \\
\hline (7) Dividend & $0.2915^{* * *}$ & $0.3134 * * *$ & $0.0481^{* * *}$ & 0.0251 & $-0.3487^{* * *}$ & 0.0198 & 1.0000 & \\
\hline (8) ROA & $0.2435 * * *$ & $0.2880^{* * *}$ & $-0.0034^{* * *}$ & $0.1517^{* * *}$ & $-0.1751^{* * *}$ & $0.1162^{* * *}$ & $0.5000^{* * *}$ & 1.0000 \\
\hline
\end{tabular}

\section{Empirical Results}

\subsection{Foreign Ownership and Firm Value}

\subsubsection{Results from the Baseline Regression}

We test the relationship between foreign ownership and firm value using the following regression:

$$
\begin{gathered}
\text { Tobin_Q } Q_{i, t}=\beta_{0}+\beta_{1} \text { Foreign_Own }_{i, t}+\beta_{2} \text { Control_Own }_{i, t}+\beta_{3} \text { Firm_Size }_{i, t} \\
+\beta_{4} \text { Leverage }_{i, t}+\beta_{5} \text { Capital_Expen }_{i, t}+\beta_{6} \text { Dividend }_{i, t}+\beta_{7} \text { ROA }_{i, t} \\
+\Sigma_{i, t} \text { Year_Dummy }+\Sigma_{i, t} \text { Industry_Dummy }_{\left(\Sigma_{i, t} F_{1} \text { Firm_Dummy }\right)+\varepsilon_{i, t}}
\end{gathered}
$$

where the dependent variable, Tobin_Q, is a proxy for firm value. The subscript $i$ and $t$ represent a firm $i$ during the fiscal year $t$. The main variable of interest is Foreign_Own. Regarding the pooled OLS and firm fixed-effects regressions as well as a dynamic-panel generalized method of moments (GMM) estimator suggested by Arellano and Bond [42], we use robust standard errors clustered at the firm level. In particular, the dynamic-panel GMM estimation method can mitigate potential endogeneity problems associated with time-varying omitted variables and simultaneity. With respect to the Fama-MacBeth [43] cross-sectional regression, statistical significance is based on the Newey and West [44] standard errors that correct the heteroscedasticity. We control for year and industry fixed effects in the pooled OLS regression and the dynamic-panel GMM estimation specification. We also include industry dummies in the Fama-MacBeth [43] cross-sectional regression and year dummies in the firm fixed-effect panel regression. All variables are defined in Appendix A.

Table 3 presents the results from four different regression specifications. We find that the coefficient on Foreign_Own is positive and significant across four columns (1) through (4), consistent with our prediction that foreign ownership is positively related to firm value. This finding is consistent with Ferreira and Matos [3], who show that firms with high foreign ownership have high firm value. We also find that the coefficients on the control variables are fairly consistent in all columns. Specifically, the coefficient on Control_Own is negative and significant, indicating that firms with higher controlling shareholders' ownership have lower firm value. Consistent with the finding in Lang and Stulz [41], we find a negative and significant coefficient on Firm_Size in columns (1) and (3). These findings indicate that larger firms have lower firm value. The coefficient on Leverage is positive and significant in all columns except for column (4), indicating that firms with high leverage have high firm value. This finding is consistent with Ferreira and Matos [3]. We find a positive and significant coefficient on Capital_Expen in columns (1) through (3), suggesting that firms with more investments have higher firm value. The coefficient on Dividend is positive and significant across all four columns, consistent with our prediction that firms with high dividend payout ratios have higher firm value. We also find 
that the coefficient on ROA is positive and significant, indicating that firms with higher profitability have higher firm value. This finding is consistent with Aggarwal et al. [4] who document that firms with high profitability have high firm value.

Table 3. The relationship between foreign ownership and firm value.

\begin{tabular}{|c|c|c|c|c|}
\hline \multirow[b]{3}{*}{ Independent Variables } & \multicolumn{4}{|c|}{ Dependent Variable $=$ Tobin_Q } \\
\hline & \multicolumn{4}{|c|}{ Four Different Estimation Specifications: } \\
\hline & $\begin{array}{l}\text { Pooled OLS } \\
\text { (1) }\end{array}$ & $\begin{array}{c}\text { Fama-MacBeth } \\
\text { (1973) } \\
\text { (2) }\end{array}$ & $\begin{array}{l}\text { Firm Fixed Effects } \\
\text { (3) }\end{array}$ & $\begin{array}{l}\text { GMM } \\
\text { (4) }\end{array}$ \\
\hline Intercept & $\begin{array}{c}1.1967^{* * *} \\
(0.002)\end{array}$ & $\begin{array}{c}1.0894^{* *} \\
(0.015)\end{array}$ & $\begin{array}{c}2.7630^{* * *} \\
(0.001)\end{array}$ & $\begin{array}{l}1.4621 * \\
(0.054)\end{array}$ \\
\hline Foreign_Own & $\begin{array}{l}0.8157^{* * *} \\
(<0.001)\end{array}$ & $\begin{array}{c}0.6585^{* * *} \\
(<0.001)\end{array}$ & $\begin{array}{c}0.5093^{* * *} \\
(0.001)\end{array}$ & $\begin{array}{l}1.1049^{* * * *} \\
(<0.001)\end{array}$ \\
\hline Control_Own & $\begin{array}{c}-0.2530 * * * \\
(0.008)\end{array}$ & $\begin{array}{c}-0.2487^{* * *} \\
(<0.001)\end{array}$ & $\begin{array}{c}-0.1823 * \\
(0.085)\end{array}$ & $\begin{array}{c}-0.4522 * * \\
(0.020)\end{array}$ \\
\hline Firm_Size & $\begin{array}{c}-0.0321 \text { ** } \\
(0.022)\end{array}$ & $\begin{array}{c}-0.0204 \\
(0.139)\end{array}$ & $\begin{array}{c}-0.0837^{* *} \\
(0.007)\end{array}$ & $\begin{array}{c}-0.0422 \\
(0.137)\end{array}$ \\
\hline Leverage & $\begin{array}{l}0.5618^{* * *} \\
(<0.001)\end{array}$ & $\begin{array}{l}0.6985^{* * *} \\
(<0.001)\end{array}$ & $\begin{array}{l}0.3758^{* * *} \\
(<0.001)\end{array}$ & $\begin{array}{l}0.2119 \\
(0.145)\end{array}$ \\
\hline Capital_Expen & $\begin{array}{c}0.2798^{* * *} \\
(0.003)\end{array}$ & $\begin{array}{c}0.2937^{* * *} \\
(0.005)\end{array}$ & $\begin{array}{c}0.2013^{* * *} \\
(0.006)\end{array}$ & $\begin{array}{c}-0.3673^{* * *} \\
(<0.001)\end{array}$ \\
\hline Dividend & $\begin{array}{l}1.3842^{* * * *} \\
(<0.001)\end{array}$ & $\begin{array}{c}11.2760 * * * \\
(<0.001)\end{array}$ & $\begin{array}{l}8.2010^{* * * *} \\
(<0.001)\end{array}$ & $\begin{array}{l}1.1946^{* * *} \\
(<0.001)\end{array}$ \\
\hline ROA & $\begin{array}{l}2.2375 * * * \\
(<0.001)\end{array}$ & $\begin{array}{l}1.4036^{* * *} \\
(<0.001)\end{array}$ & $\begin{array}{l}1.7457^{* * *} \\
(<0.001)\end{array}$ & $\begin{array}{l}1.0844^{* * *} \\
(<0.001)\end{array}$ \\
\hline Year fixed effects & Yes & No & Yes & Yes \\
\hline Industry fixed effects & Yes & Yes & No & Yes \\
\hline Firm fixed effects & No & No & Yes & No \\
\hline Adjusted $\mathrm{R}^{2}$ & 0.3097 & 0.4638 & 0.6608 & \\
\hline Number of observations & 8348 & 8348 & 8348 & 6742 \\
\hline
\end{tabular}

Note: ${ }^{* * *}, * *$, and $*$ denote significance at the $1 \%, 5 \%$, and $10 \%$ levels, respectively (two-tailed test). The $p$-values are in parentheses. For the columns (1), (3) and (4), we use robust standard errors clustered at the firm level. For the column (2), we use Newey and West [44] standard errors that correct the heteroscedasticity. In the analysis, we measure Firm_Size as the natural logarithm of the book value of total assets. As a robustness check, we follow Dang et al. [45] and repeat our analysis using two alternative proxies for firm size: (i) the natural logarithm of total sales and (ii) the natural logarithm of market capitalization. The untabulated results show that our main results remain qualitatively similar to those reported in Table 3. All variables are defined in Appendix A.

\subsubsection{Results from Change Regressions}

We estimate the pooled regression with changes in variables to examine the impact of changes in foreign ownership ( $\Delta$ Foreign_Own) on changes in firm value ( $\Delta$ Tobin_Q). We use change regressions to control for time-invariant effects that can affect firm value. Due to missing values in variable changes, our sample size is reduced to 7497 observations.

Table 4 reports the results of the pooled regression with changes in variables. We find that the coefficient on $\Delta$ Foreign_Own is positive and significant across all three columns, indicating that changes in foreign ownership are positively related to changes in firm value. The coefficient on $\Delta$ Control_Own is negative and significant in columns (2) and (3), suggesting that changes in controlling shareholders' ownership is negatively related to changes in firm value. In column (3), we find a negative and significant coefficient on $\Delta$ Firm_Size. The coefficients on $\Delta$ Leverage, $\Delta$ Capital_Expen, $\Delta$ Dividend, and $\triangle R O A$ are positive and significant. Taken together, these results confirm our previous findings on the basis of variable levels. 
Table 4. The relationship between changes in foreign ownership and changes in firm value.

\begin{tabular}{cccc}
\hline & \multicolumn{3}{c}{ Dependent Variable $=\Delta$ Tobin_Q } \\
\hline Independent Variables & $\mathbf{( 1 )}$ & $\mathbf{( 2 )}$ & $\mathbf{( 3 )}$ \\
\hline Intercept & $0.0111^{* * *}$ & $0.0158^{* * *}$ & $0.0318^{* * *}$ \\
& $(<0.001)$ & $(<0.001)$ & $(<0.001)$ \\
$\Delta$ Foreign_Own & $1.0410^{* * *}$ & $1.0190^{* * *}$ & $0.9065^{* * *}$ \\
& $(<0.001)$ & $(<0.001)$ & $(<0.001)$ \\
$\Delta$ Control_Own & & $-0.3363^{* * *}$ & $-0.2663^{* * *}$ \\
& & $(0.002)$ & $(0.009)$ \\
$\Delta$ Firm_Size & & & $-0.1801^{* * *}$ \\
& & & $(<0.001)$ \\
$\Delta$ Leverage & & & $0.5218^{* * *}$ \\
$\Delta$ Capital_Expen & & & $(<0.001)$ \\
$\Delta$ Dividend & & & 0.0516 \\
& & & $(0.312)$ \\
$\Delta$ ROA & & & $4.9053^{* * *}$ \\
Year fixed effects & Yes & $(<0.001)$ \\
Industry fixed effects & Yes & Yes & $1.3154^{* * *}$ \\
Adjusted $R^{2}$ & 0.1150 & 0.1178 & $(<0.001)$ \\
Number of observations & 7497 & 7497 & Yes \\
\hline
\end{tabular}

Note: ${ }^{* * *},{ }^{* *}$, and ${ }^{*}$ denote significance at the $1 \%, 5 \%$, and $10 \%$ levels, respectively (two-tailed test). The $p$-values are in parentheses. We use robust standard errors clustered at the firm level. All variables are defined in Appendix A.

\subsection{The Effect of Changes in Foreign Ownership on Changes in Agency Costs}

We test the first hypothesis (H1) that changes in foreign ownership is negatively associated with changes in agency costs using the following regression:

$$
\begin{aligned}
& \Delta \text { Agency_Costs } \mathrm{i}_{\mathrm{i}, \mathrm{t}}=\beta_{0}+\beta_{1} \Delta \text { Foreign_Own }_{\mathrm{i}, \mathrm{t}}+\beta_{2} \Delta \text { Control_Own } n_{\mathrm{i}, \mathrm{t}}+\beta_{3} \Delta \text { Short_Debt }_{\mathrm{i}, \mathrm{t}} \\
& +\beta_{4} \Delta \text { Firm_Size }_{i, t}+\beta_{5} \Delta \text { Leveragei }, t+\beta_{7} \Delta \text { Sales_Growth }{ }_{i, t}+\beta_{8} \Delta \text { Firm_Age }_{i, t} \\
& +\Sigma_{\mathrm{i}, \mathrm{t}} \text { Year_Dummy }+\Sigma_{\mathrm{i}, \mathrm{t}} \text { Industry_Dummy }+\varepsilon_{\mathrm{i}, \mathrm{t}} \text {. }
\end{aligned}
$$

When we take first differences $(\Delta)$, our sample size is reduced from 8348 to 7497 observations. We use three alternative proxies for agency costs, i.e., the expense ratio (SGA_Sales), net SGA_Sales, and the asset utilization ratio (Sales_Asset). Specifically, we follow Singh and Davidson III [38] and measure the expense ratio as the ratio of selling, general, and administrative (SG\&A) expenses to total sales. A lower expense ratio indicates higher agency costs. Following Ang et al. [17] and Singh and Davidson III [38], we also calculate the asset utilization ratio as the ratio of total sales to total assets. A higher utilization ratio indicates lower agency costs and more efficient asset utilization. We include both year and industry fixed effects in Equation (2). All variables are defined in Appendix A.

Table 5 reports the results of the pooled OLS regressions using three proxies for agency costs. In columns (1) and (2), we find that the coefficient on $\Delta$ Foreign_Own is negative and significant, suggesting that firms with higher changes in foreign ownership have lower changes in expense ratios. Column (3) shows that the coefficient on $\Delta$ Foreign_Own is positive and significant, indicating that firms with higher changes in foreign ownership have higher changes in asset utilization ratios. These findings are consistent with our first hypothesis (H1) that firms with higher changes in foreign ownership have lower changes in agency costs.

Regarding control variables, the coefficient on $\Delta$ Control_Own is negative and significant in column (3), indicating that that firms with higher changes in controlling shareholders' ownership have greater changes in agency costs. The coefficient on $\Delta$ Short_Debt is positive and significant in column (3), suggesting that firms with a higher proportion of short-term debt have lower changes in agency 
costs. We find a negative and significant coefficient on $\Delta$ Firm_Size in column (3). This finding indicates that higher changes in firm size is associated with greater changes in agency costs. The coefficient on $\Delta$ Sales_Growth is negative and significant in columns (1) and (2), while the coefficient is negative and significant in column (3). These results indicate that firms with larger changes in sales growth have lower changes in agency costs. In a similar vein, we find that changes in firm age is negatively related to changes in agency costs.

Table 5. The effect of changes in foreign ownership on changes in agency costs.

\begin{tabular}{|c|c|c|c|}
\hline \multirow[b]{2}{*}{ Independent Variables } & \multicolumn{3}{|c|}{ Dependent Variables: } \\
\hline & $\underset{\text { (1) }}{\Delta \text { SGA_Sales }}$ & $\underset{\text { (2) }}{\Delta \text { Net_SGA_Sales }}$ & $\underset{(3)}{\Delta \text { Sales_Asset }}$ \\
\hline Intercept & $\begin{array}{l}0.0054^{* * *} \\
(<0.001)\end{array}$ & $\begin{array}{l}0.0049^{* * *} \\
(<0.001)\end{array}$ & $\begin{array}{l}0.0086^{* * *} \\
(0.005)\end{array}$ \\
\hline$\Delta$ Foreign_Own & $\begin{array}{c}-0.0359 * * \\
(0.036)\end{array}$ & $\begin{array}{c}-0.0347^{* *} \\
(0.044)\end{array}$ & $\begin{array}{l}0.1181^{* *} \\
(0.036)\end{array}$ \\
\hline$\Delta$ Control_Own & $\begin{array}{c}-0.0079 \\
(0.687)\end{array}$ & $\begin{array}{c}-0.0074 \\
(0.702)\end{array}$ & $\begin{array}{l}-0.1348^{* *} \\
(0.030)\end{array}$ \\
\hline$\Delta$ Short_Debt & $\begin{array}{c}-0.0047 \\
(0.594)\end{array}$ & $\begin{array}{c}-0.0036 \\
(0.674)\end{array}$ & $\begin{array}{l}0.1041^{* * *} \\
(<0.001)\end{array}$ \\
\hline$\Delta$ Firm_Size & $\begin{array}{c}-0.0112 \\
(0.347)\end{array}$ & $\begin{array}{c}-0.0084 \\
(0.475)\end{array}$ & $\begin{array}{c}-0.4308^{* * *} \\
(<0.001)\end{array}$ \\
\hline$\Delta$ Leverage & $\begin{array}{l}0.0429 * \\
(0.054)\end{array}$ & $\begin{array}{l}0.0382 * \\
(0.079)\end{array}$ & $\begin{array}{l}0.0418 \\
(0.531)\end{array}$ \\
\hline$\Delta$ Sales_Growth & $\begin{array}{c}-0.0528^{* * *} \\
(<0.001)\end{array}$ & $\begin{array}{c}-0.0508^{* * *} \\
(<0.001)\end{array}$ & $\begin{array}{l}0.1970^{* * *} \\
(<0.001)\end{array}$ \\
\hline$\Delta$ Firm_Age & $\begin{array}{c}-0.0521^{* * *} \\
(<0.001)\end{array}$ & $\begin{array}{c}-0.0487^{* * * *} \\
(<0.001)\end{array}$ & $\begin{array}{l}0.1843^{* * *} \\
(<0.001)\end{array}$ \\
\hline Year fixed effects & Yes & Yes & Yes \\
\hline Industry fixed effects & Yes & Yes & Yes \\
\hline Adjusted $\mathrm{R}^{2}$ & 0.1119 & 0.1065 & 0.2785 \\
\hline Number of observations & 7497 & 7497 & 7497 \\
\hline
\end{tabular}

Note: ${ }^{* * *}, * *$ and ${ }^{*}$ denote significance at the $1 \%, 5 \%$, and $10 \%$ levels, respectively (two-tailed test). The $p$-values are in parentheses. We use robust standard errors clustered at the firm level. As a robustness check, following Dang et al. [45], we repeat our analysis using two alternative proxies for firm size: (i) the natural logarithm of total sales and (ii) the natural logarithm of market capitalization. The results, not reported for the sake of brevity, show that our main results are robust to these alternative proxies. All variables are defined in Appendix A.

\subsection{The Effect of Foreign Ownership on Dividend Payouts}

To test the second hypothesis (H2) that foreign ownership is positively associated with the level of dividends, we estimate the following regression:

$$
\begin{gathered}
\text { Dividend }_{\mathrm{i}, \mathrm{t}}=\beta_{0}+\beta_{1} \text { Foreign_Own }_{\mathrm{i}, \mathrm{t}}+\beta_{2} \text { Control_Own }_{\mathrm{i}, \mathrm{t}}+\beta_{3} \text { ROA }_{\mathrm{i}, \mathrm{t}} \\
+\beta_{4} \text { Capital_Expen }_{\mathrm{i}, \mathrm{t}}+\beta_{5} \text { R\&D_Intensity }_{\mathrm{i}, \mathrm{t}}+\beta_{6} \text { Firm_Size }_{\mathrm{i}, \mathrm{t}} \\
+\beta_{7} \text { Leverage }_{\mathrm{i}, \mathrm{t}}+\beta_{8} \text { Stock_Volatility }_{\mathrm{i}, \mathrm{t}}+\beta_{9} \text { Retained_Asset } \\
\mathrm{i}, \mathrm{t} \\
+\Sigma_{\mathrm{i}, \mathrm{t}} \text { Year_Dummy }+\Sigma_{\mathrm{i}, \mathrm{t}} \text { Industry_Dummy }+\varepsilon_{\mathrm{i}, \mathrm{t}} .
\end{gathered}
$$

We use the level of dividends (Dividend) as a dependent variable. The main variable of interest is Foreign_Own. We use robust standard errors clustered at the firm level. We control for year and industry fixed effects. All variables are defined in Appendix A.

Table 6 presents the results of the pooled OLS regression, Fama-MacBeth [43] cross-sectional regression, firm fixed-effect panel regression, and Tobit model using the level of dividends as a dependent variable. Furthermore, to address endogeneity issues, we also use the dynamic panel GMM estimation method proposed by Arellano and Bond [42]. In all columns (1) through (5), we find a positive and significant coefficient on Foreign_Own, supporting our second hypothesis (H2) that firms 
with high foreign ownership tend to pay more dividends. These findings are consistent with the outcome hypothesis suggested by La Porta et al. [33].

Table 6. The effect of foreign ownership on dividend payouts.

\begin{tabular}{|c|c|c|c|c|c|}
\hline \multirow[b]{2}{*}{ Independent Variables } & \multicolumn{5}{|c|}{ Dependent Variable $=$ Dividend } \\
\hline & $\begin{array}{c}\text { Pooled OLS } \\
\text { (1) }\end{array}$ & $\begin{array}{c}\text { Fama-MacBeth } \\
\text { (1973) } \\
\text { (2) }\end{array}$ & $\begin{array}{l}\text { Firm Fixed } \\
\text { Effects } \\
\text { (3) }\end{array}$ & $\begin{array}{c}\text { Tobit Model } \\
\text { (4) }\end{array}$ & $\begin{array}{l}\text { GMM } \\
(5)\end{array}$ \\
\hline Intercept & $\begin{array}{l}0.0268^{* * *} \\
(<0.001)\end{array}$ & $\begin{array}{l}0.0283^{* * *} \\
(<0.001)\end{array}$ & $\begin{array}{c}0.0428 * * * \\
(0.003)\end{array}$ & $\begin{array}{l}0.0117 \\
(0.115)\end{array}$ & $\begin{array}{c}0.0595^{* * *} \\
(0.001)\end{array}$ \\
\hline Foreign_Own & $\begin{array}{l}0.0131 * * * \\
(<0.001)\end{array}$ & $\begin{array}{c}0.0130 * * * \\
(<0.001)\end{array}$ & $\begin{array}{l}0.0166^{* * *} \\
(<0.001)\end{array}$ & $\begin{array}{l}0.0108^{* * *} \\
(<0.001)\end{array}$ & $\begin{array}{c}0.0119^{* * *} \\
(0.003)\end{array}$ \\
\hline Control_Own & $\begin{array}{l}0.0024 \\
(0.136)\end{array}$ & $\begin{array}{l}0.0022 * * * \\
(<0.001)\end{array}$ & $\begin{array}{c}-0.0007 \\
(0.678)\end{array}$ & $\begin{array}{c}0.0046^{* *} \\
(0.014)\end{array}$ & $\begin{array}{c}-0.0018 \\
(0.372)\end{array}$ \\
\hline ROA & $\begin{array}{l}0.0393^{* * *} \\
(<0.001)\end{array}$ & $\begin{array}{l}0.0434^{* * *} \\
(<0.001)\end{array}$ & $\begin{array}{l}0.0261^{* * *} \\
(<0.001)\end{array}$ & $\begin{array}{l}0.0846^{* * *} \\
(<0.001)\end{array}$ & $\begin{array}{l}0.0215^{* * *} \\
(<0.001)\end{array}$ \\
\hline Capital_Expen & $\begin{array}{l}0.0002 \\
(0.895)\end{array}$ & $\begin{array}{c}-0.0009 \\
(0.652)\end{array}$ & $\begin{array}{l}0.0012 \\
(0.250)\end{array}$ & $\begin{array}{c}0.0045^{* * *} \\
(0.005)\end{array}$ & $\begin{array}{c}-0.0012 \\
(0.336)\end{array}$ \\
\hline R\&D_Intensity & $\begin{array}{l}0.0030 \\
(0.774)\end{array}$ & $\begin{array}{l}0.0018 \\
(0.776)\end{array}$ & $\begin{array}{c}-0.0088 \\
(0.283)\end{array}$ & $\begin{array}{c}-0.0112 \\
(0.434)\end{array}$ & $\begin{array}{c}-0.0092 \\
(0.440)\end{array}$ \\
\hline Firm_Size & $\begin{array}{c}-0.0008^{* * *} \\
(<0.001)\end{array}$ & $\begin{array}{l}-0.0009 \\
(<0.001)\end{array}$ & $\begin{array}{c}-0.0013 \text { ** } \\
(0.019)\end{array}$ & $\begin{array}{c}-0.0004 \text { * } \\
(0.081)\end{array}$ & $\begin{array}{c}-0.0020^{* * *} \\
(0.004)\end{array}$ \\
\hline Leverage & $\begin{array}{c}-0.0068^{* * *} \\
(<0.001)\end{array}$ & $\begin{array}{l}-0.0068 \\
(<0.001)\end{array}$ & $\begin{array}{c}-0.0064^{* * *} \\
(<0.001)\end{array}$ & $\begin{array}{c}-0.0049^{* * *} \\
(0.009)\end{array}$ & $\begin{array}{c}-0.0054^{* * *} \\
(0.008)\end{array}$ \\
\hline Stock_Volatility & $\begin{array}{c}-0.00000^{* * *} \\
(<0.001)\end{array}$ & $\begin{array}{c}-0.0001 * * * \\
(<0.001)\end{array}$ & $\begin{array}{c}-0.0000^{* * *} \\
(<0.001)\end{array}$ & $\begin{array}{c}-0.0001 * * * \\
(<0.001)\end{array}$ & $\begin{array}{c}-0.0000 \\
(0.258)\end{array}$ \\
\hline Retained_Asset & $\begin{array}{l}0.0040^{* * *} \\
(<0.001)\end{array}$ & $\begin{array}{c}0.0025^{* *} \\
(0.014)\end{array}$ & $\begin{array}{c}0.0029 * * * \\
(0.001)\end{array}$ & $\begin{array}{l}0.0122 * * * \\
(<0.001)\end{array}$ & $\begin{array}{c}-0.0021 \\
(0.225)\end{array}$ \\
\hline Year fixed effects & Yes & No & Yes & Yes & Yes \\
\hline Industry fixed effects & Yes & Yes & No & Yes & Yes \\
\hline Firm fixed effects & No & No & Yes & No & No \\
\hline Adjusted $\mathrm{R}^{2}$ & 0.4225 & 0.4947 & 0.6981 & & \\
\hline Number of observations & 8348 & 8348 & 8348 & 8348 & 6742 \\
\hline Number of left-censored obs. & & & & 2290 & \\
\hline Number of uncensored obs. & & & & 6058 & \\
\hline
\end{tabular}

Note: $* * * * *$, and ${ }^{*}$ denote significance at the $1 \%, 5 \%$, and $10 \%$ levels, respectively (two-tailed test). The $p$-values are in parentheses. For the columns (1), (3), (4), and (5), we use robust standard errors clustered at the firm level. For the column (2), we use Newey and West [44] standard errors that correct the heteroscedasticity. Following Dang et al. [45], we also repeat our analysis using two alternative proxies for firm size: (i) the natural logarithm of total sales and (ii) the natural logarithm of market capitalization. The untabulated results show that our main results remain robust to these alternative proxies. All variables are defined in Appendix A.

Turning to control variables, we find a positive and significant coefficient on Control_Own in columns (2) and (4). The coefficient on ROA is positive and significant across columns (1) to (5), indicating that firms with higher profitability pay more dividends. We find no relationship between capital expenditures and dividend payouts, except for column (4). Similarly, we find that the coefficient on R\&D_Intensity is not significant. The coefficient on Firm_Size is negative and significant in all columns except for column (2), indicating that larger firms tend to pay fewer dividends. We find a negative and significant coefficient on Leverage in columns (1), (3), (4), and (5). These findings indicate that firms with higher leverage pay fewer dividends. The coefficient on Stock_Volatility is negative and significant in columns (1) through (4), suggesting that firms with higher stock volatility tend to have a lower level of dividend payouts. We find a positive and significant coefficient on Retained_Asset across columns (1) to (4), indicating that firms with higher retained earnings pay more dividends. 


\subsection{The Effect of Foreign Ownership on the Relationship between Dividend Payouts and Long-Term Firm Growth}

To test the third hypothesis (H3) that dividend payouts is positively related to long-term firm growth in firms with high foreign ownership, we estimate the following regression:

$$
\begin{aligned}
& \text { Long-Term_Growth } \mathrm{i}_{\mathrm{i}, \mathrm{t}+\mathrm{k}}=\beta_{0}+\beta_{1} \text { Dividend }_{\mathrm{i}, \mathrm{t}}+\beta_{2} \text { Dividend }^{*} \text { Foreign_Dummy } \mathrm{i}_{\mathrm{i}, \mathrm{t}} \\
& +\beta_{3} \text { Foreign_Dummy }_{\mathrm{i}, \mathrm{t}}+\beta_{4} \text { Firm_Size }_{\mathrm{i}, \mathrm{t}}+\beta_{5} \text { Leverage }_{\mathrm{i}, \mathrm{t}} \\
& +\beta_{6} \text { ROA }_{i, t}+\beta_{7} \text { Capital_Expen }_{i, t}+\beta_{8} R \& D \_ \text {Intensity } i, t \\
& +\beta_{9} \text { Firm_Age }{ }_{i, t}+\beta_{10} \text { Asset_Growth }{ }_{i, t} \\
& +\Sigma_{\mathrm{i}, \mathrm{t}} \text { Year_Dummy }+\Sigma_{\mathrm{i}, \mathrm{I}} \text { Industry_Dummy }+\varepsilon_{\mathrm{i}, \mathrm{t}} \text {, }
\end{aligned}
$$

where Long-Term_Growth $\mathrm{i}_{\mathrm{i}, \mathrm{t}+\mathrm{k}}$ is the annually compounded growth in sales (or earnings) for firm $i$ from year $\mathrm{t}$ to year $t+k$. To capture long-term firm growth (Long-Term_Growth), we follow Dempsey et al. [19] and use 3-year-ahead and 5-year-ahead sales growth as each dependent variable. We further use 3-year-ahead and 5-year-ahead earnings growth as an alternative dependent variable. The main variable of interest is an interaction term, Dividend*Foreign_Dummy. We use robust standard errors clustered at the firm level. We control for year and industry fixed effects. All variables are defined in Appendix A.

Table 7 presents the results of the pooled OLS regressions using the 3-year-ahead and 5-year-ahead sales growth. Regarding the Sales_Growth $(t+3)$ and Sales_Growth $(t+5)$ using each dependent variable, columns (1) and (2) show a negative and significant coefficient on Dividend, indicating that firms with a higher level of dividends tend to have lower long-term sales growth (or firm growth). These results are consistent with Dempsey et al. [19], who find a negative relationship between dividend payouts and 3-year-ahead and 5-year-ahead sales growth. Interestingly, we find a positive and significant coefficient on Dividend * Foreign_Dummy. This finding indicates that the relationship between dividend payouts and long-term firm growth is positive in firms with high foreign ownership, consistent with our third hypothesis (H3). In addition, we find a negative and significant coefficient on Foreign_Dummy, suggesting that firms with higher foreign ownership have lower long-term firm growth. With respect to the Earnings_Growth $(t+3)$ and Earnings_Growth $(t+5)$ using each dependent variable, columns (3) and (4) show that there is a negative and significant association between Dividend and Earnings_Growth $(t+3)$ and $(t+5)$. We further find that the coefficient on Dividend*Foreign_Dummy is positive and significant, supporting our third hypothesis (H3). Moreover, we find that the coefficient on Foreign_Dummy is negative and significant in column (3). Overall, these findings are consistent with our third hypothesis (H3) that dividend payouts are positively related to long-term firm growth in firms with high foreign ownership.

With respect to control variables, the coefficient on Firm_Size is negative and significant in columns (1) and (2), but is not significant in columns (3) and (4). Similarly, we find inconsistent results regarding the relationship between leverage and long-term firm growth. The coefficient on Capital_Expen is positive and insignificant, while the coefficient on R\&D_Intensity is positive and significant in columns (1) through (3). These results indicate that firms with higher R\&D intensity have higher long-term firm growth. We find a negative and significant coefficient on Firm_Age across all columns (1) to (4), suggesting that older firms have lower long-term firm growth. The coefficient on Asset_Growth is positive and significant in columns (1) and (2), indicating that firms with higher asset growth rates have higher long-term firm growth. 
Table 7. The effect of foreign ownership on the relationship between dividend payouts and long-term firm growth.

\begin{tabular}{|c|c|c|c|c|}
\hline \multirow[b]{2}{*}{ Independent Variables } & \multicolumn{4}{|c|}{ Dependent Variables: } \\
\hline & $\begin{array}{c}\text { Sales_Growth }(t+3) \\
(1)\end{array}$ & $\underset{(2)}{\text { Sales_Growth }(t+5)}$ & $\begin{array}{c}\text { Earnings_Growth } \\
(t+3) \\
(3)\end{array}$ & $\begin{array}{c}\text { Earnings_Growth } \\
(\mathrm{t}+5) \\
(4)\end{array}$ \\
\hline Intercept & $\begin{array}{l}0.3448^{* * *} \\
(<0.001)\end{array}$ & $\begin{array}{l}0.3100^{* * *} \\
(<0.001)\end{array}$ & $\begin{array}{l}0.4888^{* * *} \\
(<0.001)\end{array}$ & $\begin{array}{c}0.4006^{* * *} \\
(0.001)\end{array}$ \\
\hline Dividend & $\begin{array}{c}-1.8303^{* * *} \\
(<0.001)\end{array}$ & $\begin{array}{c}-1.5415^{* * *} \\
(<0.001)\end{array}$ & $\begin{array}{c}-5.7676^{* * *} \\
(<0.001)\end{array}$ & $\begin{array}{c}-3.6407^{* * *} \\
(<0.001)\end{array}$ \\
\hline $\begin{array}{l}\text { Dividend * } \\
\text { Foreign Dummy }\end{array}$ & $\begin{array}{l}1.7523^{* * *} \\
(<0.001)\end{array}$ & $\begin{array}{c}1.5020^{* * *} \\
(0.001)\end{array}$ & $\begin{array}{l}2.9481^{* * *} \\
(0.007)\end{array}$ & $\begin{array}{l}1.8983^{* *} \\
(0.020)\end{array}$ \\
\hline Foreign_Dummy & $\begin{array}{l}-0.0167^{* *} \\
(0.030)\end{array}$ & $\begin{array}{c}-0.0151^{* *} \\
(0.036)\end{array}$ & $\begin{array}{c}-0.0419 * * \\
(0.026)\end{array}$ & $\begin{array}{c}-0.0205 \\
(0.135)\end{array}$ \\
\hline Firm_Size & $\begin{array}{c}-0.0062^{* *} \\
(0.016)\end{array}$ & $\begin{array}{c}-0.0050^{* *} \\
(0.038)\end{array}$ & $\begin{array}{c}-0.0005 \\
(0.921)\end{array}$ & $\begin{array}{c}-0.0046 \\
(0.230)\end{array}$ \\
\hline Leverage & $\begin{array}{c}-0.0413^{* *} \\
(0.011)\end{array}$ & $\begin{array}{c}-0.0424^{* * *} \\
(0.009)\end{array}$ & $\begin{array}{c}0.1103^{* * * *} \\
(0.009)\end{array}$ & $\begin{array}{c}0.0911^{* * *} \\
(0.001)\end{array}$ \\
\hline $\mathrm{ROA}$ & $\begin{array}{c}-0.0625 \\
(0.183)\end{array}$ & $\begin{array}{c}-0.0402 \\
(0.365)\end{array}$ & $\begin{array}{c}-0.8124^{* * *} \\
(<0.001)\end{array}$ & $\begin{array}{c}-0.4760^{* * *} \\
(<0.001)\end{array}$ \\
\hline Capital_Expen & $\begin{array}{l}0.0485 \\
(0.104)\end{array}$ & $\begin{array}{l}0.0377 \\
(0.103)\end{array}$ & $\begin{array}{l}0.0009 \\
(0.992)\end{array}$ & $\begin{array}{l}0.0285 \\
(0.609)\end{array}$ \\
\hline R\&D_Intensity & $\begin{array}{c}0.5737^{* * *} \\
(0.004)\end{array}$ & $\begin{array}{l}0.3684^{* *} \\
(0.038)\end{array}$ & $\begin{array}{l}0.6494 * \\
(0.073)\end{array}$ & $\begin{array}{l}0.2984 \\
(0.291)\end{array}$ \\
\hline Firm_Age & $\begin{array}{c}-0.0162^{* * *} \\
(<0.001)\end{array}$ & $\begin{array}{c}-0.0171^{* * *} \\
(<0.001)\end{array}$ & $\begin{array}{c}-0.0236^{* * *} \\
(0.010)\end{array}$ & $\begin{array}{c}-0.0272 * * * \\
(<0.001)\end{array}$ \\
\hline Asset_Growth & $\begin{array}{l}0.1202 * * * \\
(<0.001)\end{array}$ & $\begin{array}{l}0.0564 * * * \\
(<0.001)\end{array}$ & $\begin{array}{l}0.0115 \\
(0.749)\end{array}$ & $\begin{array}{c}-0.0361 \\
(0.112)\end{array}$ \\
\hline Year fixed effects & Yes & Yes & Yes & Yes \\
\hline Industry fixed effects & Yes & Yes & Yes & Yes \\
\hline Adjusted $\mathrm{R}^{2}$ & 0.1175 & 0.1830 & 0.0568 & 0.0848 \\
\hline Number of observations & 6032 & 4751 & 4765 & 3658 \\
\hline
\end{tabular}

Note: ${ }^{* * *},{ }^{* *}$, and ${ }^{*}$ denote significance at the $1 \%, 5 \%$, and $10 \%$ levels, respectively (two-tailed test). The $p$-values are in parentheses. We use robust standard errors clustered at the firm level. As a robustness check, following Dang et al. [45], we repeat our analysis using two alternative proxies for firm size: (i) the natural logarithm of total sales and (ii) the natural logarithm of market capitalization. The untabulated results show that our main are qualitatively similar to those reported in Table 7. All variables are defined in Appendix A.

\section{Conclusions}

In this study, we investigate the foreign ownership-firm value relationship in the context of dividend payouts and long-term firm growth. Our findings can be summarized as follows. First, we find that foreign ownership is positively related to firm value, consistent with prior studies. Second, we find that changes in foreign ownership are negatively associated with changes in agency costs, which is linked to the improvement of future firm profitability. Third, we find that foreign ownership is positively associated with dividend payouts. Taken together, these findings suggest that a firm's improved profitability due to the reduction in agency costs is more likely to be associated with an increase in dividend payouts. Finally, for firms with high foreign ownership, we find that dividend payouts are positively associated with long-term firm growth, indicating that foreign ownership has a moderating effect on dividend payouts and long-term firm growth. This result implies that as foreign ownership increases a firm's long-term growth rates, the effects of increased long-term growth rate in the future may be incorporated into firm valuation in the current year.

Our study sheds light on the role of foreign investors in a firm's sustainable growth by showing the value-increasing effects of foreign ownership on firm value. In the Korean corporate governance system, corporate insiders (especially controlling shareholders) have exerted a significant influence on managerial decisions. Corporate governance is highly concentrated for controlling shareholders [46]. Controlling shareholders have an incentive to expropriate gains from minority shareholders for the pursuit of their private interests $[47,48]$. Controlling shareholders may pressure managers to give up potentially value-enhancing long-term projects. Foreign investors are expected to discipline managers and controlling shareholders to seek a value-enhancing long-term strategy. On the other hand, domestic institutional investors may not effectively monitor and discipline corporate insiders, 
e.g., CEOs and controlling shareholders. Domestic institutional investors are mostly chaebol-affiliated and are heavily influenced by controlling shareholders in chaebols. This is due to the fact that controlling shareholders take control over chaebol affiliates through cross-shareholdings [48] and pyramid ownership structures $[49,50]$. Likewise, outside directors are usually selected based on personal ties with CEOs or controlling shareholders and, thus, their monitoring role is limited. In contrast, foreign investors are recognized as having a weak tie with corporate insiders; thus, they may not be influenced by corporate insiders. That is, foreign investors can serve as effective, external monitors of corporate insiders [3] and influence the strategic decision-making activities of firms [51]. Based on the above discussion, foreign investors as important corporate governance and ownership entities are expected to have a significant impact on a firm's sustainable growth.

Our study holds important implications for policy decision makers, stakeholders, and regulators in emerging markets. In the situation in which domestic institutional investors are recognized as ineffective monitors in the corporate governance system, foreign investors can help improve corporate governance and investor protection in emerging markets. Emerging markets are heavily dependent on foreign capital inflows to develop their economic growth, implying that foreign investors can exert an influence on corporate policies. In particular, policy decision makers and regulators in emerging markets are concerned that foreign investors are more likely to seek short-term profits, which will adversely affect a firm's long-term prospect. Some commentators and news media sources also claim that foreign investors demand an extremely high level of dividends. Given the negative views toward foreign investors, we highlight the important role of foreign investors in the Korean stock markets, one of the leading emerging markets, by showing that foreign investors have the potential to enhance firm value, which possibly suggests that the benefits from foreign ownership outweigh the negative views.

Our study has at least five limitations as follows. First, we study the value-increasing avenues of foreign ownership in the Korean stock market. Many Korean firms have unique ownership structures, such as family business conglomerates known as chaebols. Thus, one should carefully interpret our findings when applied to firms in the developed countries. Second, we use foreign ownership as a main explanatory variable, but do not consider specific types of foreign investors, i.e., transient or dedicated institutional investors, due to the limitation of data availability. Bushee $[52,53]$ classifies the U.S. institutional investors into transient, dedicated, and quasi-indexing institutions based on their past investment patterns or behaviors. Therefore, further research should examine the value effects of foreign ownership on firm value using specific types of foreign investors. Third, as an additional analysis, it is worthwhile to investigate the relationship among foreign institutional ownership, agency costs, and firm value in the context of corporate social responsibility (CSR). For example, Li et al. [54] provide evidence against an over-investment hypothesis as the finding shows the negative relationship CEO power and CSR activities. They also emphasize the value-enhancing role of CSR by showing that CSR is positively related to firm value. Based on their study, it can be predicted that if foreign institutional ownership encourages firms to engage in more CSR and thus increases corporate image, their firm value increases. Fourth, we cannot definitively rule out the possibility of omitted variable bias in the foreign ownership-firm value relationship. In our empirical analysis, due to the limitation of data availability, we are not able to control for variables capturing corporate governance mechanisms, such as CEO compensation incentives [55], market competition [56], mutual monitoring among the executives [57], and CEO tournaments [58]. Thus, further research should consider these omitted variables that can affect the association between foreign ownership and firm value. Fifth, as $\mathrm{Li}$ [59] points out, the issue of endogeneity has been one of the main concerns in empirical corporate finance. This endogeneity bias may distort the estimated coefficients from a regression analysis. Thus, in our empirical analysis, to address endogeneity concerns, we employ the fixed effect model and the dynamic-panel GMM estimator. Our empirical results are robust to these econometric specifications that can be effective in mitigating endogeneity concerns. However, one cannot completely address the endogeneity issue. Therefore, further research should consider alternative specifications, e.g., an instrumental variable (IV) specification, to overcome endogeneity problems. 
Author Contributions: Y.M.C. designed the paper, collected the data, developed the hypotheses, and performed the empirical analysis. K.P. summarized the literature review, contributed to the hypothesis development, conducted the empirical analysis, and finalized the manuscript. All authors discussed the contributions and wrote the paper.

Funding: This research received no external funding.

Acknowledgments: We gratefully acknowledge the comments and suggestions of three anonymous referees.

Conflicts of Interest: The authors declare no conflict of interest.

\section{Appendix A. Variable Definitions}

\begin{tabular}{|c|c|}
\hline Variables & Definition \\
\hline Tobin_Q & $\begin{array}{l}\text { Tobin's } Q \text {, calculated as the book value of total assets plus the market value of equity } \\
\text { minus the book value of equity, divided by the book value of total assets. }\end{array}$ \\
\hline Foreign_Own & $\begin{array}{l}\text { Sum of common and restricted stock owned by the foreign investors, divided by shares } \\
\text { outstanding at the fiscal year end. }\end{array}$ \\
\hline Control_Own & $\begin{array}{l}\text { Sum of common and restricted stock owned by the controlling shareholders, divided by } \\
\text { shares outstanding at the fiscal year end. }\end{array}$ \\
\hline Firm_Size & Natural logarithm of the book value of total assets. \\
\hline Leverage & Total debt divided by total assets. \\
\hline Capital_Expen & Capital expenditures divided by total assets. \\
\hline Dividend & Cash dividends divided by total assets. \\
\hline ROA & $\begin{array}{l}\text { Return on total assets, calculated as the earnings before interest and tax (EBIT) divided by } \\
\text { total assets. }\end{array}$ \\
\hline SGA_Sales & Selling, general, and administrative (SG\&A) expenses divided by total sales. \\
\hline Sales_Asset & Net sales divided by total assets. \\
\hline Short_Debt & $\begin{array}{l}\text { Proportion of short-term debt, measured as the ratio of short-term debt that matures in one } \\
\text { year to a firm's total debt. }\end{array}$ \\
\hline Sales_Growth & Change in net sales from the previous year, divided by lagged net sales. \\
\hline Firm_Age & Natural logarithm of 1 plus the number of years since establishment of a firm. \\
\hline Stock_Volatility & $\begin{array}{l}\text { Standard deviation of daily stock price returns multiplied by the square root of the number } \\
\text { of trading days in a year. }\end{array}$ \\
\hline R\&D_Intensity & Research and development (R\&D) expenses divided by total sales. \\
\hline Retained_Asset & Retained earnings divided by total assets. \\
\hline Asset_Growth & Change in total assets from the previous year, divided by the lagged total assets. \\
\hline Foreign_Dummy & $\begin{array}{l}\text { An indicator variable equal to one if a firm's foreign ownership is more than the yearly } \\
\text { median foreign ownership and zero otherwise. }\end{array}$ \\
\hline Sales_Growth $(t+k)$ & {$\left[\left(\frac{\text { Sales }_{i, t+k}}{\text { Sales }_{i, t}}\right)^{\frac{1}{k}}\right]-1$, where $k=3$ and 5 for 3- and 5-year-ahead periods. } \\
\hline Earnings_Growth $(\mathrm{t}+\mathrm{k})$ & $\left.\left(\frac{\text { Earnings }_{i, t+k}}{\text { Earnings }_{i, t}}\right)^{\frac{1}{k}}\right]-1$, where $k=3$ and 5 for 3 - and 5 -year-ahead periods. \\
\hline
\end{tabular}

\section{References}

1. Khanna, T.; Palepu, K. Business Groups, Foreign Intermediaries, and Corporate Governance. In Concentrated Corporate Ownership; Morck, R.K., Ed.; University of Chicago Press: Chicago, IL, USA, 2000; pp. 265-292.

2. Douma, S.; George, R.; Kabir, R. Foreign and domestic ownership, business groups, and firm performance: Evidence from a large emerging market. Strateg. Manag. J. 2006, 27, 637-657. [CrossRef]

3. Ferreira, M.A.; Matos, P. The colors of investors' money: The role of institutional investors around the world. J. Financ. Econ. 2008, 88, 499-533. [CrossRef]

4. Aggarwal, R.; Erel, I.; Ferreira, M.; Matos, P. Does governance travel around the world? Evidence from institutional investors. J. Financ. Econ. 2011, 100, 154-181. [CrossRef]

5. Grossman, S.J.; Hart, O.D. Takeover bids, the free-rider problem, and the theory of the corporation. Bell J. Econ. 1980, 11, 42-64. [CrossRef]

6. Shleifer, A.; Vishny, R.W. Large shareholders and corporate control. J. Political Econ. 1986, 94, 461-488. [CrossRef]

7. Mehran, H. Executive compensation structure, ownership, and firm performance. J. Financ. Econ. 1995, 38, 163-184. [CrossRef] 
8. Grinstein, Y.; Michaely, R. Institutional holdings and payout policy. J. Financ. 2005, 60, 1389-1426. [CrossRef]

9. Campbell II, T.L.; Keys, P.Y. Corporate governance in South Korea: The chaebol experience. J. Corp. Financ. 2002, 8, 373-391. [CrossRef]

10. Chang, S.J.; Hong, J. How much does the business group matter in Korea? Strateg. Manag. J. 2002, 23, 265-274. [CrossRef]

11. Mishra, A.V.; Ratti, R.A. Governance, monitoring and foreign investment in Chinese companies. Emerg. Mark. Rev. 2011, 12, 171-188. [CrossRef]

12. Huang, W.; Zhu, T. Foreign institutional investors and corporate governance in emerging markets: Evidence of a split-share structure reform in China. J. Corp. Financ. 2015, 32, 312-326. [CrossRef]

13. Oxelheim, L.; Randøy, T. The impact of foreign board membership on firm value. J. Bank. Financ. 2003, 27, 2369-2392. [CrossRef]

14. Choi, J.J.; Park, S.W.; Yoo, S.S. The value of outside directors: Evidence from corporate governance reform in Korea. J. Financ. Quant. Anal. 2007, 42, 941-962. [CrossRef]

15. Jeon, J.Q.; Ryoo, J. How do foreign investors affect corporate policy? Evidence from Korea. Int. Rev. Econ. Financ. 2013, 25, 52-65. [CrossRef]

16. Jeon, J.Q.; Lee, C.; Moffett, C.M. Effects of foreign ownership on payout policy: Evidence from the Korean market. J. Financ. Mark. 2011, 14, 344-375. [CrossRef]

17. Ang, J.S.; Cole, R.A.; Lin, J.W. Agency costs and ownership structure. J. Financ. 2000, 55, 81-106. [CrossRef]

18. Ibbotson, R.G.; Chen, P. Long-run stock returns: Participating in the real economy. Financ. Anal. J. 2003, 59, 88-98. [CrossRef]

19. Dempsey, M.; Gunasekarage, A.; Truong, T.T. The association between dividend payout and firm growth: Australian evidence. Account. Financ. 2018. Forthcoming. [CrossRef]

20. Myers, S.C. The capital structure puzzle. J. Financ. 1984, 39, 575-592. [CrossRef]

21. Jensen, M.C.; Meckling, W.H. Theory of the firm: Managerial behavior, agency costs and ownership structure. J. Financ. Econ. 1976, 3, 305-360. [CrossRef]

22. Jensen, M.C. Agency costs of free cash flow, corporate finance, and takeovers. Am. Econ. Rev. 1986, 76, 323-329.

23. Weisbach, M.S. Outside directors and CEO turnover. J. Financ. Econ. 1988, 20, 431-460. [CrossRef]

24. Borokhovich, K.A.; Parrino, R.; Trapani, T. Outside directors and CEO selection. J. Financ. Quant. Anal. 1996, 31, 337-355. [CrossRef]

25. Anderson, R.C.; Reeb, D.M. Founding-family ownership and firm performance: Evidence from the S\&P 500. J. Financ. 2003, 58, 1301-1328. [CrossRef]

26. Gillian, S.; Starks, L.T. Corporate Governance, Corporate Ownership, and the Role of Institutional Investors: A Global Perspective, Weinberg Center for Corporate Governance (Working Paper). 2003. Available online: https: / / ssrn.com/abstract=439500 (accessed on 14 July 2018).

27. Zeckhauser, R.J.; Pound, J. Are Large Shareholders Effective Monitors? An Investigation of Share Ownership and Corporate Performance. In Asymmetric Information, Corporate Finance, and Investment; Hubbard, G.R., Ed.; University of Chicago Press: Chicago, IL, USA, 1990; pp. 149-180.

28. Eckbo, B.E.; Verma, S. Managerial shareownership, voting power, and cash dividend policy. J. Corp. Financ. 1994, 1, 33-62. [CrossRef]

29. Short, H.; Zhang, H.; Keasey, K. The link between dividend policy and institutional ownership. J. Corp. Financ. 2002, 8, 105-122. [CrossRef]

30. Baba, N. Increased presence of foreign investors and dividend policy of Japanese firms. Pac. Basin Financ. J. 2009, 17, 163-174. [CrossRef]

31. The Economist. Minority Report: Corporate Governance Explains South Korea's Low Stockmarket Ratings. 2012. Available online: https:/ / www.economist.com/finance-and-economics/2012/02/11/minority-report (accessed on 22 August 2018).

32. Chang, S.J. Ownership structure, expropriation, and performance of group-affiliated companies in Korea. Acad. Manag. J. 2003, 46, 238-253. [CrossRef]

33. La Porta, R.; Lopez-de-Silanes, F.; Shleifer, A.; Vishny, R.W. Agency problems and dividend policies around the world. J. Financ. 2000, 55, 1-33. [CrossRef]

34. Higgins, R.C. How much growth can a firm afford? Financ. Manag. 1977, 6, 7-16. [CrossRef] 
35. Fama, E.F.; French, K.R. Disappearing dividend: Changing firm characteristics or lower propensity to pay? J. Financ. Econ. 2001, 60, 3-43. [CrossRef]

36. Farsio, F.; Geary, A.; Moser, J. The relationship between dividends and earnings. J. Econ. Educ. 2004, 4, 1-5.

37. Gill, A.; Biger, N.; Tibrewala, R. Determinants of dividend payout ratios: Evidence from the United States. Open Bus. J. 2010, 3, 8-14. [CrossRef]

38. Singh, M.; Davidson III, W.N. Agency costs, ownership structure and corporate governance mechanisms. J. Bank. Financ. 2003, 27, 793-816. [CrossRef]

39. Benson, B.W.; Davidson III, W.N. Reexamining the managerial ownership effect on firm value. J. Corp. Financ. 2009, 15, 573-586. [CrossRef]

40. Berger, P.G.; Ofek, E. Diversification's effect on firm value. J. Financ. Econ. 1995, 37, 39-65. [CrossRef]

41. Lang, L.H.P.; Stulz, R.M. Tobin's q, corporate diversification, and firm performance. J. Political Econ. 1994, 102, 1248-1280. [CrossRef]

42. Arellano, M.; Bond, S. Some tests of specification for panel data: Monte Carlo evidence and an application to employment equations. Rev. Econ. Stud. 1991, 58, 277-297. [CrossRef]

43. Fama, E.F.; MacBeth, J.D. Risk, return, and equilibrium: Empirical tests. J. Political Econ. 1973, 81, $607-636$. [CrossRef]

44. Newey, W.K.; West, K.D. A simple, positive semi-definite, heteroskedasticity and autocorrelation consistent covariance matrix. Econometrica 1987, 55, 703-708. [CrossRef]

45. Dang, C.; Li, Z.; Yang, C. Measuring firm size in empirical corporate finance. J. Bank. Financ. 2018, 86, 159-176. [CrossRef]

46. Kim, J.-B.; Yi, C.H. Foreign versus domestic institutional investors in emerging markets: Who contributes more to firm-specific information flow? China J. Account. Res. 2015, 8, 1-23. [CrossRef]

47. Johnson, S.; La Porta, R.; Lopez-De-Silanes, F.; Shleifer, A. Tunneling. Am. Econ. Rev. 2000, 90, $22-27$. [CrossRef]

48. Bae, K.-H.; Kang, J.-K.; Kim, J.-M. Tunneling or value added? Evidence from mergers by Korean business groups. J. Financ. 2002, 57, 2695-2740. [CrossRef]

49. Baek, J.-S.; Kang, J.-K.; Park, K.S. Corporate governance and firm value: Evidence from the Korean financial crisis. J. Financ. Econ. 2004, 71, 265-313. [CrossRef]

50. Chang, J.J.; Shin, H.-H. Family ownership and performance in Korean conglomerates. Pac. Basin Financ. J. 2007, 15, 329-352. [CrossRef]

51. Bena, J.; Ferreira, M.A.; Matos, P.; Pires, P. Are foreign investors locusts? The long-term effects of foreign institutional ownership. J. Financ. Econ. 2017, 126, 122-146. [CrossRef]

52. Bushee, B.J. The influence of institutional investors on myopic R\&D investment behavior. Account. Rev. 1998, 73, 305-333.

53. Bushee, B.J. Do institutional investors prefer near-term earnings over long-run value? Contemp. Account. Res. 2001, 18, 207-246. [CrossRef]

54. Li, F.; Li, T.; Minor, D. CEO power, corporate social responsibility, and firm value: A test of agency theory. Int. J. Manag. Financ. 2016, 12, 611-628. [CrossRef]

55. Core, J.; Guay, W. The use of equity grants to manage optimal equity incentive levels. J. Account. Econ. 1999, 28, 151-184. [CrossRef]

56. Giroud, X.; Mueller, H.M. Corporate governance, product market competition, and equity prices. J. Financ. 2011, 66, 563-600. [CrossRef]

57. Li, Z. Mutual monitoring and corporate governance. J. Bank. Financ. 2014, 45, 255-269. [CrossRef]

58. Coles, J.L.; Li, Z.; Wang, A.Y. Industry tournament incentives. Rev. Financ. Stud. 2018, 31, 1418-1459. [CrossRef]

59. Li, F. Endogeneity in CEO power: A survey and experiment. Invest. Anal. J. 2016, 45, 149-162. [CrossRef]

(C) 2019 by the authors. Licensee MDPI, Basel, Switzerland. This article is an open access article distributed under the terms and conditions of the Creative Commons Attribution (CC BY) license (http:/ / creativecommons.org/licenses/by/4.0/). 